\title{
PENERAPAN PENDEKATAN KONSTRUKTIVISME UNTUK MENINGKATKAN KEMAMPUAN DAN HASIL BELAJAR MENULIS PADA PESERTA DIDIK
}

\author{
Arif Supriyadi \\ Milah \\ Universitas MuhammadiyahPalangka raya
}

\begin{abstract}
Abstrak: Penelitian ini bertujuan untuk mengetahui aktivitas kemampuan dan hasil belajar Bahasa Indonesia peserta didik menggunakan Pendekatan Konstruktivisme tahun pelajaran 2014/2015. Jenis penelitian ini merupakan penelitian tindakan kelas (PTK). Instrumen yang digunakan berupa observasi dan tes. Subjek dalam penelitian ini adalah seluruh peserta didik kelas V SDN 1 Mandomai. Nilai aktivitas peserta didik pada siklus I mencapai angka 2,64 dalam kategori cukup baik dan mengalami peningkatan pada siklus II menjadi 4 amat baik. Sedangkan nilai rata-rata hasil belajar peserta didik pada siklus I mencapai nilai ratarata 40 dalam keterangan tidak tuntas dan mengalami peningkatan pada siklus II menjadi nilai rata-rata 86,5 dalam keterangan tuntas. Pada siklus I ke siklus II meningkat 46,5\% atau sebesar $45 \%$.
\end{abstract}

Kata Kunci: Konstruktivisme, Belajar, Kemampuan, Menulis.

\section{PENDAHULUAN}

Menurut Sudrajat (2009), pendidikan dapat dilihat dalam dua sisi yaitu : (1) pendidikan sebagai praktik, dan (2) pendidikan sebagai teori. Pendidikan sebagai praktik yakni seperangkat kegiatan atau aktivitas yang dapat diamati dan disadari dengan tujuan untuk membantu pihak lain (baca : peserta didik) agar memperoleh perubahan perilaku. Sementara pendidikan sebagai teori yaitu seperangkat pengetahuan yang telah tersusun secara sistematis yang berfungsi untuk menjelaskan, menggambarkan, meramalkan, dan mengontrol berbagai gejala dan peristiwa pendidikan, baik yang bersumber dari pengalaman-pengalaman pendidikan (empiris) maupun hasil perenungan-perenungan yang mendalam untuk melihat makna pendidikan dalam konteks yang lebih luas.

Dalam keseluruhan proses pendidikan di sekolah, kegiatan belajar mengajar merupakan kegiatan yang paling pokok. Hal itu berarti berhasil atau tidaknya pencapaian tujuan pendidikan bergantung pada proses belajar yang dialami oleh peserta didik sebagai anak didik. Pada Pendidikan formal ( sekolah ) salah satu masalah pokok dalam pembelajaran adalah masih rendahnya daya serap peserta didik. Hal ini nampak hasil peserta didik yang senantiasa masih sangat memperihatikan. Prestasi ini tentunya merupakan hasil kondisi pembelajari anak didik yang masih bersifat konvensional dan tidak menyentuh ranah dimensi peserta didik itu sendiri, yaitu bagaimana sebenarnya belajar itu.

Dalam proses pembelajaran hingga saat ini masih memberikan akses bagi anak didik untuk berkembang secara mandiri melalui penemuan dan proses berpikirnya.Maka oleh sebeb itu penelitian ini dilakukan agar lebih mengetahui lebih jelas dimana masalah yang muncul akan dapat teratasi dan sesuai dengan tuntutan Kurikulum Tingkat Satuan Pendidikan KTSP. Penelitian tindakan kelas ini dilakukan untuk menggali masalah dari 
kenyataan-kenyataan yang terdapat di lingkungan pendidikan dan dengan tuntutan yang relevan sesuai dengan Kurikulum Tingkat Satuan Pendidikan KTSP yang di inginkan. Demikian, untuk mengetahui permasalahan yang terjadi dalam proses pengajaran bahasa diperlukan diskusi kolaboratif dengan guru mata pelajaran. Berdasarkan hasil observasi dan dengan guru peserta didik kelas V SDN 1 Mandomai tahun pembelajaran 2015/2016 tentang menulis slogan diketahui dari 25 peserta didik dan 20 peserta didik memperoleh nilai di bawah KKM dan hanya 5 peserta didik yang memperoleh nilai di atas KKM atau dari jumlah peserta didik yang tuntas. Hal ini berarti peserta didik kelas V SDN 1 Mandomai tahun pembelajaran 2015/2016 belum mencapai syarat ketuntasan minimal. Dan selain itu, berdasakan hasil observasi dan dengan guru bidang studi bahasa Indonesia di kelas V SDN 1 Mandomai didapatkan bahwa peserta didik kelas V SDN 1 Mandomai tahun pembelajaran 2015/2016 mengalami kesulitan dalam pembelajaran menulis khususnya menulis slogan. Peserta didik terkadang sulit membedakan ciri-ciri slogan dengan konteks. Kegiatan pembelajaran di sekolah menunjukkan kegiatan pembelajaran menulis belum optimal.

Hal tersebut ditunjukkan kurang mampunya peserta didik dalam mengemukakan pendapat dan gagasannya secara kreatif serta kurang mampu mendapatkan dan mengumpulkan informasi yang aktual sebagai bahan tulisan. Penyebab ketidakoptimalan tersebut antara lain dikarenakan pendekatan yang digunakan oleh guru kurang tepat, guru masih mendominasi kelas dan kurang memberi kesempatan kepada peserta didik untuk berkreasi, mengekspresikan diri secara bebas. Ketika pembelajaran menulis ditentukan oleh guru. Hak otonomi peserta didik untuk berkreasi, mengekspresikan, melukiskan jati dirinya atau lingkungan sekitarnya sesuai pengalamannya menjadi terkekang. Untuk membantu peserta didik memahami konsep-konsep dan memudahkan guru dalam mengajarkan konsep-konsep tersebut diperlukan suatu pendekatan pembelajaran yang langsung mengaitkan materi konteks pelajaran dengan pengalaman nyata dalam kehidupan seharihari, seperti halnya mereka bisa melihat dan mengalami pengalaman itu kemudian menuangkan kedalam ide mereka masingmasing tentang apa yang mereka lihat di sekitarnya.

Realita pembelajaran yang seperti ini membawa dampak kurang baik untuk peserta didk. Peserta didik mengalami kesulitan ketika harus menulis slogan dan poster. Peserta didik bingung apa yang harus ia lakukan untuk mengerjakan tugas tersebut. Sulit menemukan data yang aktual dan faktual serta menarik untuk bahan menulis slogan dan poster tidak tahu bagaimana dan dari mana mesti memulai menulisnya. Belum lagi, perasaan takut salah, takut berbeda dengan apa yang diinstruksikan oleh gurunya sehingga respon peserta didk terhadap pelajaran menulis berkurang dan pada akhirnya menghilangkan minat pserta didik dalam menulis slogan, dan poster.

Pola pembelajaran menulis yang dikembangkan sangat berstruktur dan mekanis, mulai dari penentuan topik, penyeragaman kerangka tidaklah selamanya bijaksana,dengan adanya penyeragaman topik, penyeragaman pola, menyebabkan kreativitas peserta didik menjadi kurang berkembang. Peserta didik merasa materi tersebut asing karena skemata/informasi awal tentang tema/topik yang akan ditulis tersebut kurang memadai. Akibatnya, pembelajaran menulis menjadi kering, tidak menarik, dan tidak bermakna. Peserta didik akan kehilangan gairah dalam mengikuti pembelajaran menulis sehingga keterampilan peserta didik dalam menulis khususnya dalam menulis slogan dan poster menjadi terhambat. 
Untuk itu saya sebagai peneliti berupaya menerapkan pendekatan konstruktivisme ini untuk membantu memecahkan masalah tersebut.

Dalam studi pendahuluan, melalui pengamatan dan dengan guru kelas dan peserta didik kelas V SDN I Mandomai tahun pembelajaran 2015/2016 pembelajaran menulis di antaranya menulis slogan dan puisi kurang memaksimalkan kemampuan speserta didik . Hal tersebut dapat dilihat pada: (1) peserta didik kesulitan dalam menemukan menulis perbedaan slogan, poster dan puisi; (2) peserta didik kurang mempunyai data yang aktual dan faktual sebagai bahan untuk mengidentifikasi jenis-jenis slogan dan puisi. Berdasarkan hal tersebut, masalah yang dihadapi para peserta didik adalah kesulitan memperoleh data yang aktual, faktual, dan menarik sebagai bahan menulis slogan dan poster. Salah satu penyebabnya adalah kurangnya keterlibatan dan kesempatan yang diberikan kepada peserta didik untuk mengalami langsung dalam proses menulis slogan dan poster mereka hanya menerima ceramah, penjelasan dan tugas yang ada dibuku saja, sedangkan tugas yang sepenuhnya pada saat menulis slogan mereka masih belum bisa. Jangankan untuk menuangkan ide mereka tentang lingkungan dan sebagainya memahami arti slogan dan poster saja mereka masih belum bisa.

Oleh karena itu, peneliti berkolaborasi dengan guru kelas untuk merancang sebuah pembelajaran yang mampu peserta didik termotivasi selama mengikuti proses belajar-mengajar. Salah satu alternatif dalam penelitian ini, yaitu menerapkan pendekatan pembelajaran konstruktivisme.

Pendekatan konstruktivisme ini dikembangkan oleh Piaget dan Vigotsky. Menurut teori perkembangan kognitif Piaget Perkembangan kognitif sebagian besar ditentukan oleh manipulasi dan intraksi aktif anak dengan lingkungan. Pengetahuan datang dari tindakan. Piaget yakin bahwa pengalaman-pengalaman fisik dan manipulasi lingkungan penting bagi terjadinya perubahan perkembangan. Dengan dasar tersebut pembelajaran harus dikemsa menjadi proses " mengkonstruk" bukan "menerima" penegetahuan. Dalam prose pembelajaran peserta didk membangun sendiri pengetahuan mereka melalui keterlibatan aktif dalam proses belajar mengajar. Peserta didik menjadi pusat kegiatan bukan guru.

Pembelajaran dengan pendekatan konstruktivis me ini digunakan agar peserta didik mampu menemukan masalah (sering muncul dari peserta didk sendiri ) dan selanjutnya membantu peserta didik menyelesaikan dan menemukan langkahlangkah pemecahan masalah tersebut. Pendekatan Konstruktivisme didasarkan pada belajar kogntif yang menekankan pada pembelajaran kooperatif, pembelajaran generatif, bertanya, inkuiri atau menemukan dan keterampilan metakognitif lainnya (Suyatno, 2004:33).

Dengan menyoroti latar belakang tersebut, pendekatan konstruktivisme dipilih sebagai alternatif tindakan dalam pengajaran dalam menulis karena pendekatan ini dianggap sebagai cara yang efektif untuk mengarahkan seluruh potensi peserta didik sehingga lebih termotivasi selama mengikuti proses belajar-mengajar yang berdampak positif pada hasil belajarnya.

Pendekatan konstruktivisme adalah ide bahwa peserta didik harus secara individu menemukan dan menerapkan informasi-informasi yang kompleks ke dalam situasi lain apabila mereka harus menjadikan informasi itu miliknya sendiri. Pendekatan konstruktivisme ini memandang peserta didik secara terusmenerus memeriksa informasi-informasi baru yang berlawanan dengan aturanaturan lama dan memperbaiki aturanaturan tersebut jika tidak sesuai lagi. Pandangan ini mempunyai keterlibatan yang mendalam dalam pengajaran, sebagaimana diuraikan terdahulu bahwa pendekatan ini menganjurkan peranan 
yang lebih aktif bagi peserta didik dalam pembelajaran mereka sendiri dibandingkan dengan apa yang saat ini dilaksanakan pada mayoritas kelas. Nur ( 2001:2). Konstruktivisme merupakan suatu pendekatan yang penekanannya berpusat pada peserta didik yang aktif, pendekatan konstruktivisme sering disebut pengajaran yang terpusat pada peserta didik atau student centered instruction.

Di dalam kelas yang terpusat padapeserta didik, peran guru adalah membantu peserta didik menemukan fakta, konsep atau prinsip bagi diri mereka sendiri, bukan memberikan ceramah atau mengendalikan seluruh kegiatan kelas. M.Nur, (2001:2).

\section{METODOLOGI}

Waktu pelaksanaan penelitian ini adalah pada saat semester ganjil selama 4 bulan. Dimulai pada bulan Maret sampai bulan Juni 2015. Tindakan dilaksanakan pada waktu proses pembelajaran berlangsung, sehingga ketika mengajar sambil mengadakan tindakan sesuai pembelajaran berbasis masalah yang telah ditentukan dan sekaligus observasi. Penelitian kelas ini dilaksanakan di SDN I Mandomai. Ditentukan mulai Maret sampai Juni 2015. Sedangkan settingnya diterapkan pada peserta didik kelas $\mathrm{V}$ yang merupakan bagian dari anak yang memiliki motivasi rendah.

Penelitian ini merupakan penelitian tindakan kelas. Penelitian tindakan kelas adalah merupakan tindakan yang dilakukan dikelas tempat berlangsungnya proses pembelajaran. Suatu penelitian akan menghasilkan kesimpulan yang tepat, apabila menggunakan jenis penelitian yang tepat dan benar sesuai dengan masalah yang diteliti, stuasi, dan kondisi saat penelitian tersebut dilakukan.

Dalam penelitian, metode merupakan salah satu hal yang sangat penting. Dengan adanya metode tentu penelitian akan lebih terarah dan dapat dipertanggung jawabkan. Dalam penelitian ini, penelitian menggunakan metode Penelitian Tindakan Kelas ( PTK).

Menurut Sanjana (2013/26) Dari penjelasan diatas, maka PTK dapat diartikan sebagai proses pengkajian masalah pembelajaran di dalam kelas melalui refleksi diri dalam upaya untuk memecahkan masalah tersebut dengan cara melakukan berbagai tindakan yang terencana dalam situasi nyata serta menganalisis setiap pengaruh dari perilaku tersebut.

Menurut pendapat lain tentang penelitian tindakan dikemukakan oleh Sanjaya (2013/25 ) Yang menyatakan bahwa penelitian tindakan adalah penerapan berbagai fakta yang ditemukan untuk memecahkan masalah dalam situasi sosial untuk meningkatkan kualitas tindakan yang dilakukan dengan melibatkan kolaborasi dan kerja sama para peneliti dan praktis.

Subjek penelitian adalah peserta didik kelas V semester 2 tahun pelajaran 2014/2015. Jumlah keseluruhan subjek adalah 25 peserta didik, tang terdiri dari 8 laki-laki dan 18 perempuan.

Untuk mengetahui penelitian ini maka didalam kelas pengajaran harus memiliki subjek penelitian. Untuk meluruskan penelitian ini sumber utamanya adalah seluruh peserta didik kelas V.

\section{Siklus I}

1. Perencanaan

Dalam tahap ini guru menetapkan segala instrumen yang akan digunakan dalam penelitian antara lain, lembar pengamatan aktivitas guru dan peserta didk, rencana pelaksanaan pembelajaran, bahan dan media pembelajaran, menyusun soal dari angket respon peserta didk.

2. Pelaksanaan Tindakan

Kegiatan pembelajaran dengan berpedoman pada 
pelaksanaan Pembelajaran ( RPP ) Yang telah disusun. Pada kegiatan ini, dilakukan kegiatan sebagai berikut :

1. Kegiatan Awal meliputi :

$$
\begin{aligned}
& \text { - Guru mengucapkan } \\
& \text { salam, berdo'a, } \\
& \text { memeriksa kehadiran } \\
& \text { peserta didik dan } \\
& \text { mengkondisikan } \\
& \text { peserta didik untuk siap } \\
& \text { belajar. }
\end{aligned}
$$

2. Kegiatan inti ;

- Guru menyampaikan topik pembelajaran menganai menulis khusnya menulis slogan.

- Guru menyampaikan tujuan pembelajaran dan memeberikan apersepsi selama sepuluh menit kepada peserta didk .

- Guru menunjukan contoh slogan dan yang di ambil dari guntingan koran dan majalah kepada peserta didk.

- Guru dan peserta didk sama-sama terlibat dalam proses pemebelajaran, namun guru hanya sebagai mediator, peserta didk yang harus aktif dan bertangungg jawab atas pembelajarannya.
3. Kegitan penutup ;

- Guru dan peserta didik menyimpulkan materi mengenai " Slogan dan Poster "

- Guru memberikan kesempatan kepada peserta didik untuk bertanya.

- Guru memmajang hasil karya terbaik dimajalah dinding

- Guru menutup kegiatan dengan mengucapkan Do'a dan salam

2. Obsesvasi

Dalam tahap observasi, peneliti mengamati perilaku dan perubahan sikap yang terjadi pada peserta didk setelah di terapkannya tindakan kelas dan dibantu oleh seseorang pengamat yaitu teman sejawat atau guru pamong tersebut. Pengamat mengamati proses pembelajaran sesuai dengan instrumen yang tersedia. Instrumen meliputi aktivitas guru dan peserta didk dikelas, dan hasil tes dan data respon terhadap pembelajaran menulis slogan dengan pendekatan konstruktivisme.

3. Refleksi

\begin{tabular}{lr}
\multicolumn{1}{c}{ Refleksi ini dilakukan } \\
dengan mengadakan evaluasi \\
tindakan yang telah dilakukan. \\
Kemudian \\
pertemuan untuk melakukan \\
tentang Slogan, belajar bersamas \\
dengan guru kelas dan teman \\
sejawat. Dilanjutkan dengan \\
merencanakan perbaikan \\
pelaksanaan tindakan \\
berikutnya untuk digunakan \\
pada siklus berikutnya Siklus II.
\end{tabular}




\section{HASIL DAN PEMBAHASAN}

Data pra tindakan terdiri atas data hasil tes awal (pree test). Data awal ini bertujuan untuk mengetahui tingkat kemampuan awal peserta didik terhadap materi yang akan dijadikan topik pembelajaran sebelum penelitian tindakan kelas berlangsung. Adapun bentuk tes yang dilakukan dengan memberikan soal pilihan ganda sebanyak 10 butir soal dari pembelajaran bahasa indonesia pada materi menulis slogan dan poster. Adapun data awal dari 10 orang peserta didik terdapat 6 orang peserta didik yang mendapatkan skor hasil bahasa indonesia masih rendah yakni kurang dari KKM yang telah ditentukan oleh sekolah. Skor nilai tes awal selanjutnya dijadikan sebagai nilai dasar untuk menghitung peningkatan hasil belajar individu pada siklus I.

Tabel .1

Reakapi tul asi Hasil belajar ( Tes awal, tes akhir siklus I siklus II)

\begin{tabular}{|c|c|c|c|c|}
\hline No & $\begin{array}{c}\text { Kode } \\
\text { peserta } \\
\text { didik }\end{array}$ & $\begin{array}{c}\text { Tes } \\
\text { Awal }\end{array}$ & $\begin{array}{c}\text { Siklus } \\
\text { I }\end{array}$ & $\begin{array}{c}\text { Siklus } \\
\text { II }\end{array}$ \\
\hline 1 & SH & $\mathbf{2 0}$ & $\mathbf{2 0}$ & $\mathbf{1 0 0}$ \\
\hline 2 & AS & $\mathbf{4 0}$ & $\mathbf{2 0}$ & $\mathbf{6 0}$ \\
\hline 3 & RH & $\mathbf{4 0}$ & $\mathbf{6 0}$ & $\mathbf{8 0}$ \\
\hline 4 & NH & $\mathbf{4 0}$ & $\mathbf{4 0}$ & $\mathbf{1 0 0}$ \\
\hline 5 & FI & $\mathbf{4 0}$ & $\mathbf{4 0}$ & $\mathbf{1 0 0}$ \\
\hline 6 & RS & $\mathbf{2 0}$ & $\mathbf{4 0}$ & $\mathbf{8 0}$ \\
\hline 7 & AN & $\mathbf{4 0}$ & $\mathbf{8 0}$ & $\mathbf{8 0}$ \\
\hline 8 & PI & $\mathbf{4 0}$ & $\mathbf{4 0}$ & $\mathbf{8 0}$ \\
\hline 9 & RS & $\mathbf{6 0}$ & $\mathbf{2 0}$ & $\mathbf{8 0}$ \\
\hline 10 & RE & $\mathbf{2 0}$ & $\mathbf{6 0}$ & $\mathbf{1 0 0}$ \\
\hline 11 & DL & $\mathbf{6 0}$ & $\mathbf{6 0}$ & $\mathbf{1 0 0}$ \\
\hline 12 & MH & $\mathbf{2 0}$ & $\mathbf{4 0}$ & $\mathbf{8 0}$ \\
\hline 13 & MA & $\mathbf{6 0}$ & $\mathbf{6 0}$ & $\mathbf{1 0 0}$ \\
\hline
\end{tabular}

\begin{tabular}{|c|c|c|c|c|}
\hline 14 & SA & $\mathbf{2 0}$ & $\mathbf{8 0}$ & $\mathbf{8 0}$ \\
\hline 15 & EV & $\mathbf{2 0}$ & $\mathbf{6 0}$ & $\mathbf{1 0 0}$ \\
\hline 16 & MS & $\mathbf{2 0}$ & $\mathbf{2 0}$ & $\mathbf{8 0}$ \\
\hline 17 & NE & $\mathbf{6 0}$ & $\mathbf{2 0}$ & $\mathbf{8 0}$ \\
\hline 18 & RR & $\mathbf{6 0}$ & $\mathbf{6 0}$ & $\mathbf{8 0}$ \\
\hline 19 & RA & $\mathbf{2 0}$ & $\mathbf{4 0}$ & $\mathbf{8 0}$ \\
\hline 20 & RI & $\mathbf{2 0}$ & $\mathbf{4 0}$ & $\mathbf{8 0}$ \\
\hline 21 & AR & $\mathbf{2 0}$ & $\mathbf{4 0}$ & $\mathbf{1 0 0}$ \\
\hline & $\begin{array}{c}\text { Jmlah } \\
\mathbf{6 8 0}\end{array}$ & $\mathbf{1 0 0 0}$ & $\mathbf{2 1 4 0}$ \\
\hline Rata- & $\mathbf{2 7 , 2}$ & $\mathbf{4 0}$ & $\mathbf{1 0 0}$ \\
\hline
\end{tabular}

Berdasarkan tabel dapat dilihat bahwapadadata awal nilai rata-rata pesertadidikhanyamemperoleh nilai 27,2ini masih dibawah dari kriteriaketuntasanyangditentukanyaitu 60.Hasilketuntasan pesertadidik pun hanyamemperoleh $20 \%$. Nilai inisangat jauh dari nilai kriteriaketuntasan klasikalyangditentukanyakni

$60 \%$.Kemudian padasiklusInilai rata-rata pesertadidik meningkatmenjadi $40 \%$ namun ilai ini masih belummencapai kriteria ketuntasan yangdi tentukan.

Hasil ketuntasan klasikal belajar peserta didikpun meningkat yakni memperoleh nilai $32 \%$ nilai ini hampir mencapai

kriteriaketuntasank lasikalyangd itentukan.

Sehinggaharusmengoptimalkan lagi proses pembelajaranpadasiklusIIyang manamemperoleh nilai rata-rata $86,5 \%$ dan ketuntasan klasikalnya mencapai $100 \%$ nilai ini mengalamipeningkatan dari tindakan sebelumnyadan sudah melebihi ketuntasan yang ditentukan dari pihak sekolah.

Berdasarkan uraian data tersebutmakahasilbelajar menunjukkan peningkatan. Hal ini sesuai dengan hipotesis adapeningkatankemampuan menulis slogan dan posterdalam 
matapelajaran

denganmenggunakan

bahasaIndonesia pendekatan

konsruktivisme padapesertadidik kelas $\mathrm{V}$

SDN1 Mandomai. Berikut ini tabel

Rakapitulasi hasil belajar Siklus I dan Siklus II

\section{KESIMPULAN}

Berdasarkan hasilpenelitianyangtelah dibahas makadapat disimpulkan:

1. Aktivitas belajar pesertadidik dalampembelajaran bahasa Indonesia ketarampilan menulis slogan dan poster dengan menggunakanpendekatan

kostrutivisme padapeseta didik kelasVSDN 1 Mandomai lebihaktif danbersemangat. Adapun aktivitas belajar peserta didik dilihat dari kemampuan mereka yaitu pada siklus I kemampuan aktivitas mereka rata-rata 2,9 dan meningkat ke siklus II dengan rat-rata 3,85.

2. Adapeningkatankemampuan menulis slogan dan poster dalam matapelajaran bahasa Indonesia dengan menggunakanpendekatan konstruktivisme padapesertadidik kelasVSDN 1 Mandomai TahunPelajaran2014/2015.

Peningkatan tersebut dapat dilihat darihasilbelajar pesertadidik khususnyadalam kemampuanmenulis slogan dan poster.

3. Pada siklus I perolehan nilai rata-rata peserta didikyaitu 40 denganketuntasanklasikal 60\%dan mengalami peningkatan padasiklusIIdengan rata-ratanilai 100 danketuntasan klasikal $100 \%$.

Dari hasil penelitian yang

dilakukan maka dapat d irekomendasikan sebagai berikut:

1. Bagikepala sekolah,

diharapkanmenyarankanguru-guru untuk menggunakan pendekatan konstruktivis me padapembelajaran bahasaIndonesia agar dapatmeningkatkan kemampuan dan hasil belajar menulis slogan dan posterpada pesertadidik

2. Bagi guru, diharapkan lebih terampil dan kreatif dalam memanfaatkan dan menggunakan media pembelajaran agar peserta didik aktif, menarik perhatian, tidak bosan, serta pembelajaran yang ingin dicapai sesuai dengan hasilyang diinginkan.

\section{DAFTAR PUSTAKA}

Akhadiah, Subarti, dkk. 2004.

Ketrampilan Menulis. Jakarta.Depdikbud.

Baharuddin\&WahyuniNurEsa.2009. Teori Belajar dan Pembelajaran.Jogyakarta :Ar-Ruzz Media.

Djamrah. S.B. Zain Aswan, (2013). Strategi Belajar Mengajar. Jakarta :Rineka Cipta.

Hamalik, 2008.Proses Belajar

Mengajar.Jakarta: BumiAksara.

Harjanto. 2008. Perencanaan Pengajaran. Jakarta: Rineka Cipta.

Kiyati Djojosoroto \& M.L.A

Sumaryati.2014.Bahasa \&

Sastra.Bandung : Nuansa Cendekia

Kusumaningsih dewi,2013.Terampil

Berbahasa Indonesia. Yogyakarta :

AC.V.Andi OFFSET

Musaba, Zulkifli.2013. T erampil Menulis.

Banjarmasin: Sarjana

Indonesia. 
Nur, Muhammad. 2013. Pendekatan

Konstruktivisme.

Surabaya:UNESA.

Suyatno. 2004. Teknik Pembelajaran

Bahasa Dan Sastra. Surabaya: SIC.

Sosanto, Ahmad,2013. Teori Belajar \&

Pembelajaran.Jakarta. KENCANA.

Sigit,2013. Pembelajaran Konstruktivisme.

Bandung : ALFABETA

Sanjana, Wina.2013. Penelitian Tindakan

Kelas ( PTK ).Jakarta.KENCANA

Susanto, Ahmad. (2013). Teori Belajar \&

Pembelajaran di SekolahDasar.

Jakarta :Kencana

Sujarweni. V. Wiratna, (2014), Metodologi

Penelitian. Yogyakarta :Pustaka

Baru Press.

Tim Penyusun. (2014). Buku Pedoman

Skripsi FKIP Universitas Muhammadiyah

Palangkaraya.Palangkaraya

Trianto, 2008. Mendesain pembelajaran

kontekstual. Jakarta: Cerdas

pustaka

publisher.

Yamin,Martinis.2005. Paradigma

Pendidikan Konstruktivistik.Jakarta. GP

Pres
Hidayatullah, 2014.Meningkatkan

Keterampilan Menulis Puisi Dengan

Menggunakan Pembelajaran

Quantum Teaching Tipe Tandur

Pada SDN 3 Selat Hilir

Kapuas.Skripsi.Universitas

MuhammadiyahPalangka Raya

2010. Penilaian Hasil

Belajar Proses Belajar Mengajar.

Bandung: PT RemajaRosdakarya. 